XIAO DONG, Master ${ }^{1}$

E-mail: 981666907@qq.com

RUOYA WANG, Ph.D. ${ }^{1}$

(Corresponding author)

E-mail: zoeywry@126.com

YAODONG ZHOU, Ph.D. ${ }^{1}$

(Corresponding author)

E-mail: ydzhou@bjtu.edu.cn

${ }^{1}$ School of Economics and Management

Beijing Jiaotong University

$3^{\text {rd }}$ Shangyuancun Road, Haidian District, Beijing

100044, China
Traffic Management Original Scientific Paper Submitted: 10 Jan. 2020 Accepted: 25 May 2020

\title{
CAN NEGATIVE TRAVEL HABITS HINDER POSITIVE TRAVEL BEHAVIOURAL CHANGE UNDER BEIJING VEHICLE RESTRICTIONS?
}

\begin{abstract}
Given the rapid development of large cities, the residents faced with pressure both at work and in their personal lives tend to solidify their choice of transport modes and form personal travel habits, which in turn leads to higher requirements for urban traffic management. Based on the modified Theory of Planned Behaviour, the structural equation method is employed to explore people's travel behaviour. It is found that policy attitude, perceived behaviour control, and subjective norms comprehensively affect the residents' travel intentions under the Vehicle Restrictions in place in Beijing. The residents without private cars display a stronger intention to change their travel choices under the policies. When considering the mediating effect of travel habits between travel intention and travel choice, the impact of the restrictive policies is weakened. Compared with lower-income people, those with higher incomes demonstrate more stable travel habits in response to the effects of the restrictions. The higher the income, the greater the dependence on private cars exhibited by the residents. To summarize, people's travel habits weaken to some extent the effects of the restrictive policies. Such policies should be created with the explicit aim of gradually changing the people's habits.
\end{abstract}

\section{KEY WORDS}

travel choice; travel habits; theory of planned behaviour; structural equation model; vehicle restrictions;

\section{INTRODUCTION}

Traffic congestion in large cities, including Beijing, is one of the "megacity diseases." As of 2018 , there were more than 6.08 million vehicles in
Beijing, and the number of drivers stood at approximately 11.32 million, more than $50 \%$ of the resident population in an area covering 1.64 square kilometres [1]. The rapid growth of motor vehicles brings comfort and convenience for residents but also causes some negative externalities, including traffic congestion, environmental pollution, and accidents [2-4]. For this reason, the Transportation Demand Management (TDM) was adopted as early as in the 1990s in Europe, America and other regions to optimize the residents' transport modes by changing their travel choice, reducing the demand for private cars, and making more effective use of motor vehicles. To control the number of motor vehicles in Beijing, during the China-Africa Cooperation Forum, Beijing Summit, held in November 2006, and the "Good Luck Beijing" Competition, held in 2007, measures such as off-peak commuting and odd-even license plate restrictions were implemented for the first time. During the 2008 Beijing Olympics and Paralympics, these Vehicle Restriction policies were officially implemented for the first time. In 2008, the odd-even license plate restriction policy was implemented on July 1, September 20, and October 11, which represented an adjustment to Vehicle Restrictions. After trial and short-term implementation, Vehicle Restrictions finally serve as a long-term policy in Beijing to relieve the traffic pressure.

Vehicle Restrictions originated in Mexico City [5]. Beijing has issued a variety of relevant policies to make up for the loopholes in the initial policies of the Mexican cities, including non-local car restrictions and purchase restrictions. These measures 
have been in place for nearly 12 years, since 2008 , and they are expected to continue. The research on Beijing experience with restrictions has primarily focused on three perspectives. First, the scholars have studied the effectiveness of the policies on alleviating traffic congestion [6,7]. Wen et al. [6] pointed out that TDM measures greatly affect congestion levels. Second, the scholars have examined whether the policies have a significant impact on the residents' travel choices [8]. When compared with the influence of such policies on public transit, Wang et al. [8] revealed that the restrictive policies in Beijing do not have a significant influence on individuals' decisions to drive. Third, the scholars have examined whether the policies exhibit any negative effects [9, 10]. According to Viard and $\mathrm{Fu}[9]$, in the short term, driving restrictions can be effective in reducing pollution, but at the cost of reduced work time. Although effective, the restrictions are not the most economically efficient way to reduce pollution. These articles highlight the dispute over the long-term and short-term effectiveness of Vehicle Restrictions.

The proportion of car travel in Beijing has been relatively stable in recent years. According to the Beijing Traffic Development Annual Report [1], from 1986 to 2005, the use of cars increased significantly, as shown in Figure 1. After 2006, with the implementation of Vehicle Restrictions, the rapid growth of car travel was controlled, and the slowly declining trend was maintained. However, since 2014, a slight upward trend has been evident, reaching $33.78 \%$ in 2017 . For more than 10 years, car travel has maintained a proportion of more than $30 \%$. Does this indicate that Vehicle Restrictions in Beijing have no significant influence on the transport situation? Generally, the policies only play a short-term role. As a result of the comfort and convenience of private cars, do residents form fixed travel habits that hinder the effectiveness of Vehicle Restrictions policies?

Traffic habits are a reflection of people's normal travel choices. With regard to commuting, people rarely change their original way of travel and common routes under normal conditions. Some scholars compare these habits to mechanical behaviours, which demonstrate a repetition of past behaviour without an obvious change in the situation and the state. This means that habits exhibit characteristics that ignore new information and scenarios and preserve the inherent selection [11, 12]. Essentially speaking, innate habit is a dominant response strategy, which can be activated in memory faster than other options and can slowly modify the people's

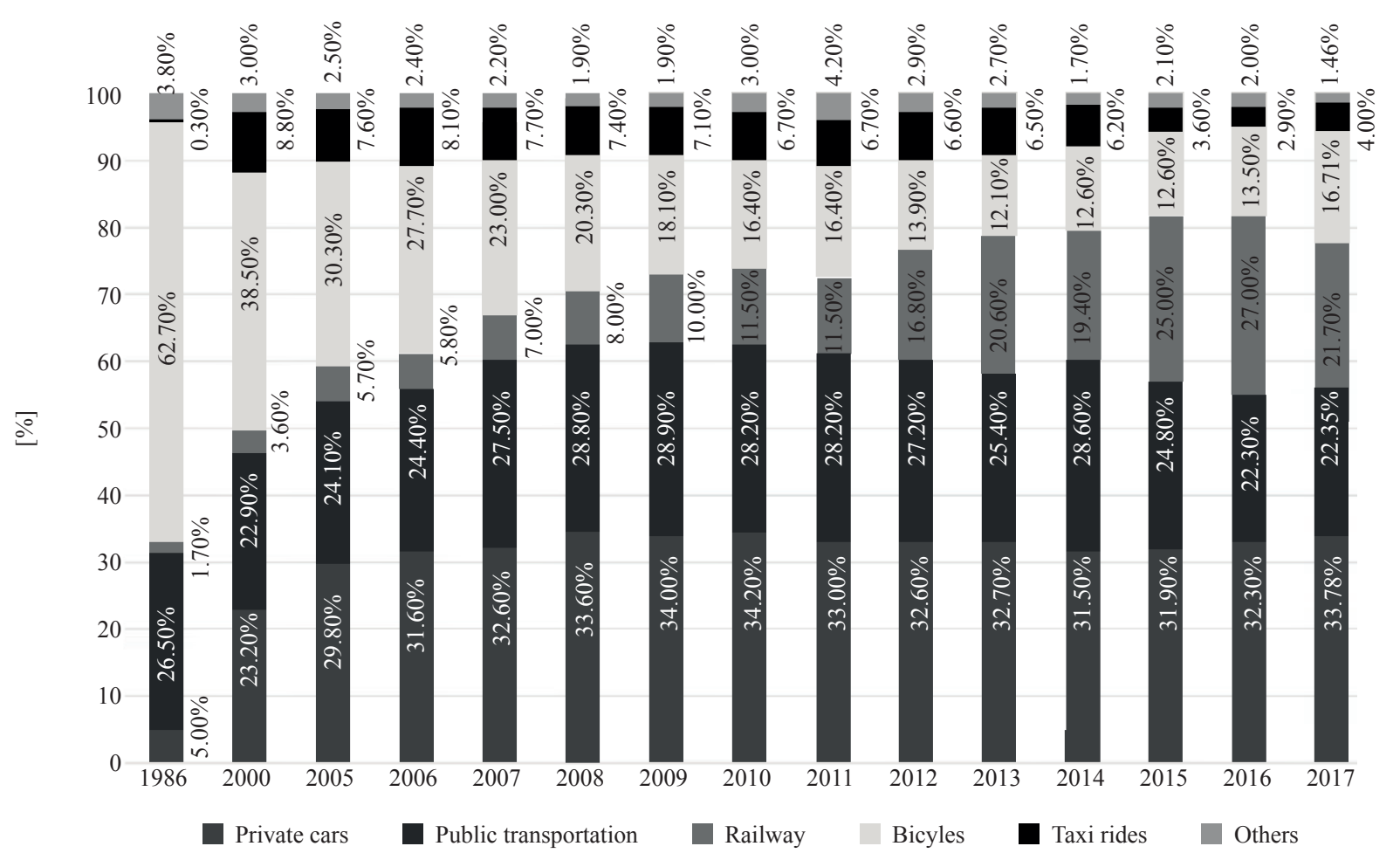

Figure 1 - The proportion of major vehicles used in Beijing Source: Beijing Transport Institute 
memory path. Time pressures, distraction and decreased self-control, all tend to reinforce people's habitual behaviour in daily life. Specifically, people tend to make choices based on their habits rather than seeking new ideas in a stable state [13]. Accordingly, there may be a blocking effect in terms of habit through the TDM policies, whose aim is to motivate or change people's travel choices, under which the effectiveness of the policies will be questioned.

It is discussed whether people's travel habits with regard to private cars will change under the Vehicle Restrictions in Beijing, and further, we explore specific conditions that bring about changes in habits. In proceeding down this path, our study makes at least two contributions to the extant literature. First, the research scope and policy background are characteristic of our contributions. We focus on people's travel behaviour in Beijing, and empirical research is established in the context of Vehicle Restrictions. This has not been fully studied by scholars to date. Second, unlike the existing literature, which has explored the direct effect of these policies, we pay attention to the role of habits in the changes in travel behaviour under the policies. More specifically, the role of travel habits is innovatively considered. The remainder of the study is organized as follows. In the next section, a brief review of relevant literature is provided. Section 3 depicts the structural equation model that has been adopted, as well as our hypotheses. We describe the detailed methods and the data in Section 4, and empirical analysis is conducted in Section 5. Section 6 offers a discussion of our findings. Section 7 features the conclusion.

\section{LITERATURE REVIEW}

The existing research on motivation in travel choice primarily focuses on three ideas. First, the traffic demand management policies, such as increasing parking fees, increasing fuel use costs and charging congestion charges are adopted to encourage residents to change their travel choice [14-17]. The second idea is derived from the external and objective factors that affect travel choice, such as urban planning, environmental characteristics, land use, etc. [18-21]. Third, scholars focus on the effect of user factors, such as demographic characteristics and psychological factors on their travel choice [22-27]. All of these studies assume that the agents make choices and adopt alternatives without cost under different scenarios and policies, or that people's responses to new scenarios are consistent and undifferentiated.

Habits can be thought of as opportunity costs people pay for choosing a new travel mode. When they have chosen one specific travel vehicle, the chance to experience other types is naturally lost. From the Theory of Planned Behaviour (TPB), early studies hold that travel habits are a persistent cognitive orientation based on goal-oriented automaticity and context-dependent stability, which is referred to as "habitual mindset" [11]. Aarts and Dijksterhuis [28] studied the automatic response mechanism of this mode of thinking. They believed that the activation of travel intention automatically activates the travel choice in people's memory, which serves as an important factor of inertial thinking. Bamberg et al. [29] posited that given the frequency of car use, neither past behaviour nor direct habit measurement can predict travel behaviour in the future when the environment changes. Conversely, Fujii and Garling [30] argued that the frequent choice of a particular travel mode causes habitual choice based on the script, and despite the script's change with the change of the environment, the long-term choice of one mode will weaken the new alternative.

The studies highlighted the above focus on the expression mechanism of travel habits. Additional studies further analyse the influence of habits on travel choice under different scenarios. Most argue that the difference between travel habits and intention is a long-term, automatic intention. Klockner and Matthies [31] contended that travel habits are influenced by personal and social values and beliefs and are the effective regulators of the relationship between personal values or beliefs and behaviours. Personal values, as noted herein, are equivalent to the intention in TPB, and social values are equivalent to social norms and moral codes. With strong habits, people's inherent travel choice is not affected by environmental and social values or beliefs. With weak habits, personal values or beliefs and travel choices have direct effects on travel choice under different intervention strategies (such as restriction strategies) or information strategies (such as environmental education). This indicates that intervention and information strategies are effective if individual choices are not influenced by habits. Thomas and Walker [32] compared the habit intensity of different traffic modes and concluded that the users who choose bicycling or walking have 
stronger habit intensity compared with those who choose private cars or public transportation. Hoang-Tung et al. [33] focused on the establishment of habits and introduced the intermediary variable of automatic intention, which is composed of past behaviour, general intention, and situational attributes, verifying the positive effect of automatic intention on the adoption of public transport. Setiawan et al. [34] studied the influencing factors of student groups' habits in reducing motor vehicle usage, and they found that the habits are the strongest influential factors in terms of personal norms and travel behaviours. These viewpoints seem to indicate the significant influence of habits in travel choice, but most of the extant literature emphasizes the positive guiding role of habits in public transportation choices, and it does not seem to explain whether those habits will be affected by any factors and migrate.

There are still controversies over the definition and measurement of habits. The primary tools for measuring habits consist of Response Frequency Measurement (RFM) and the Self-Reported Habits Index (SRHI). RFM is a possible spectrum of frequent leisure activities by which respondents choose their travel modes for each activity and comprehensively calculate the number of car trips for each person, indicating the habit of motor vehicle travel [35]. The method cannot measure the comprehensiveness of the behaviour, and it is difficult to represent the greater value and consciousness connotation of the habit using only the number of times as the index. SRHI is a universal 12-item self-reporting tool that describes and expresses habitual behavioural traits, such as historical repeatability, unconsciousness, difficulty in exercising control, and psychological values. The reliability of SRHI lies in its ability to effectively identify and predict the validity of various customary contents [36], but the subjectivity is difficult to eliminate.

Considering the long-term implementation of Vehicle Restrictions for private cars in Beijing, this study explores the influence of people's policy attitudes, subjective norms, perceived behavioural control, and travel intention on their travel choice. We have expanded TPB by adding the mediated effect of travel habits. SRHI is measured by using a questionnaire and by exploring the relationship among the multiple factors using the structural equation model. First, it is examined if travel habits affect people's behavioural solidification. Second, we explore whether people's cognition of traffic modes and policies will subtly influence the habit formation. Third, we conduct further research on the influence of habits over the travel choice, as well as the differences in policy avoidance between different income groups.

\section{MODELS AND HYPOTHESES}

As a social psychological modification of the general rational selection method [29], TPB is one of the most mature psychological models in individual decision-making. It suggests that all potential factors indirectly affect the behaviour through their impact on the subjective will. Additionally, subjective will is primarily influenced by three psychological factors, namely: perceived behaviour control, attitudes, and subjective norms. Habits are added as intermediary variables in this study. We have categorized private cars, fast taxis, rental cars, and ride-hailing cars as private cars (including taxis), because those vehicles share some of the same characteristics. As shown in Figures 2 and 3, the travel habits of private cars (including taxis) are scriptbased, which means that they not only affect travel choice with travel intention in a parallel fashion, but are also affected by travel intention. In other words, travel habits are not immutable, but are rather based upon script inertia formed under a long-term and intentionally repeated cognition. Therefore, the policy attitude, subjective norms, and perceived behaviour will indirectly affect the travel habits of private cars through travel intention, and travel habits will act as the mediating variable between travel intention and travel choice.

On this basis, it was first verified that the outcome of the questionnaire samples conforms to the general logic of TPB, and we then added habit variables to examine the impact of private car travel habits on travel choice and the effectiveness of habits under different conditions. Based on this logic, several relevant hypotheses are proposed below.

Vehicle Restrictions are considered to have a strong reduction effect on private car travel, at least in the short term, referring to both the relatively short implementation period in Mexico City or the 12year implementation period in Beijing [37]. Based on TPB, relevant literature studies have examined the relationship between policy attitude, subjective norms, perceived behaviour control, travel intention, and travel choice. The first three factors have a positive influence on people's intention to convert from private cars to public transportation $[38,39]$. 


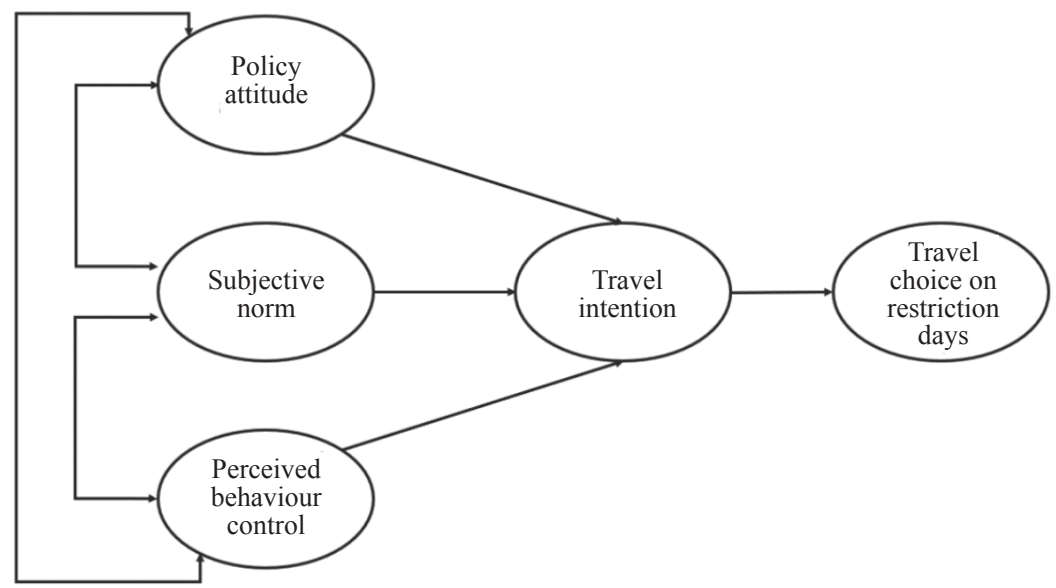

Figure 2-Model of residents' travel choice

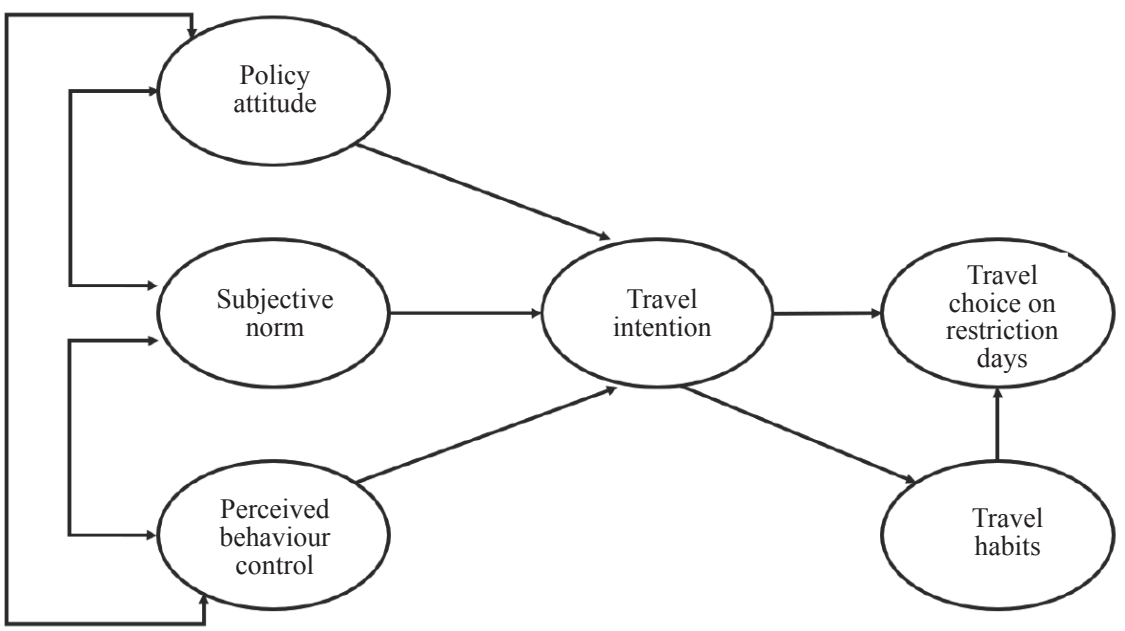

Figure 3-Model of residents'travel choice, mediated by travel habits

The travel intention of non-private cars also plays a positive role in public transport [25]. It can be inferred that this policy has a negative impact on the travel mode of private cars (including taxis).

H1. The implementation of Vehicle Restrictions exerts an influence over residents' travel choice of private car (including taxis);

H1.1. Changes in residents' attitudes toward Vehicle Restrictions have an effect on their travel intention toward non-private vehicles;

H1.2. Changes in residents' subjective norms have an effect on their travel intention toward non-private vehicles;

H1.3. Changes in residents' perceived behaviour control have an effect on their travel intention toward non-private vehicles;
H1.4. Residents' travel intention toward non-private vehicles has an effect on their travel choice of private cars (including taxis) on restricted days.

Habit is also an important factor in people's choice of the travel mode. Generally, private cars are convenient and comfortable for travel, and people form inertial thinking through repeated use. The habit intensity of car use has a positive impact on residents' travel choice of private cars (including taxis) $[40,41]$.

H2. Changes in residents' travel habits toward private cars (including taxis) have an effect on their travel choice of private cars (including taxis) on restricted days.

Consideration of the habits toward private cars may weaken the direct influence of non-habitual travel intention on travel choice, and may strengthen 
the private car travel intention. The travel intention toward non-private vehicles has an indirect negative effect on the travel choice toward private cars (including taxis). Under the influence of long-term policy cognition, it can be argued that the travel intention incurs people's travel habits, and travel habits directly affect their travel choice. Using the structural equation model, we can verify the mediating effect that travel habits may have between travel intention and travel choice.

H3. Changes in travel habits related to the use of private cars (including taxis) have a mediating effect between travel intention and travel choice on restricted days.

The disruption and migration of inherent habits may be affected by a commitment or incentive that is effective over a long term [42]. With strong habits, people are likely to ignore the effect of external changes on their behaviour. For example, on restricted days, the inertia of private car rides (including taxis) leads people to employ online car-hailing or another private car to avoid the restriction. However, there are still restrictions on people's choice, including the direct cost of purchasing and using the second private car, the idle cost of the unused car, and the extra expense of a taxi. Therefore, the influence of inertial thinking on residents' behaviour may be limited by family income. When income increases, the residents' demand for private cars increases, and more cars are purchased and used [43]. Compared with low-income groups, higher-income groups are more likely to form travel habits for private cars [44].

H4. On restricted days, the blocking effect of people's travel habits on the use of private cars (including taxis) varies among different groups of people.

Under the vehicle restriction policy and, more precisely, the odd-even license plate policy, the residents in Beijing are faced with two kinds of days for travel. Vehicles with different tail numbers are restricted on different dates. When someone cannot drive their car, there are still other ways to travel, such as taxis or ride-hailing. It must be emphasized that the definition of the private car on which this study is based is relatively loose and is not limited to cars owned by people. When their own cars are restricted, people often have the option of choosing other private cars. Therefore, it is also reasonable to study people's intentions and choices of private car travel on non-restricted days.

\section{METHODS AND DATA}

\subsection{Questionnaire design}

We designed the questionnaire, primarily referring to the basic requirements and assumptions of the structural equation, the standard questionnaire of travel choice, and the requirements of SRHI. Since the questionnaire was presented in Chinese, we have conducted translation and back-translation before using those vital variables. The questionnaire consists of personal information, policy attitude, subjective norms, perceived behaviour control, travel habits, and travel choice. Personal information consists of the basic data of residents from the perspective of demography. We investigated the residents' travel choices through their actual manner of travel on the restricted days. According to the intensity of traffic congestion and environmental pollution, we set the travel modes into five categories, i.e. walking, bicycling and the use of e-bikes, bus and rail transit, taxi and online car-hailing, and private cars. As for the remaining components, we provided the respondents with a brief explanation of latent variables in the questionnaire, and two to five observed variables were established for the four latent variables. Five-point Likert scale was used for measurement.

\subsection{Sample data}

The questionnaire was distributed through various Internet platforms (Wenjuanxing, WeChat, $\mathrm{QQ}$, etc.), aiming primarily the permanent residents of Beijing. The distribution lasted for nearly one month, from 17 July 2018 to 19 August 2018, and a total of 1,367 questionnaires were collected. Each sample contained a submission time, answer time, IP address, platform source, and the respondents' answers. Those samples with IP addresses outside Beijing were then excluded. The IP addresses also served as a restriction in the case of multiple fillings. According to our pre-survey, the fastest-reading residents could finish all of the questions in $89 \mathrm{sec}-$ onds, so we then excluded those samples finished in less than 90 seconds. After discarding the abnormal samples, the final number was 1,090 available samples, accounting for $79.74 \%$ of the total, much more than the requirement for the structural equation model.

All of the latent variables affecting travel choice were divided into three subscales. The first subscale is for TPB, including policy attitude, subjective 
Dong X, Wang R, Zhou Y. Can Negative Travel Habits Hinder Positive Travel Behavioural Change under Beijing Vehicle...

Table 1 - Description of variables and their codes

\begin{tabular}{|c|c|c|c|}
\hline $\begin{array}{c}\text { Latent } \\
\text { variables }\end{array}$ & Code & Observed variables & $\begin{array}{l}\text { Academic } \\
\text { source }\end{array}$ \\
\hline $\begin{array}{l}\text { Policy } \\
\text { attitude }\end{array}$ & ATT & $\begin{array}{l}\text { att1. Respondents' attitude on Vehicle Restrictions in Beijing. } \\
\text { att2. Respondents' attitude on the viewpoint that "Vehicle Restrictions help with } \\
\text { alleviating road congestion". } \\
\text { att3. Respondents' attitude on the viewpoint that "Vehicle Restrictions' relieve } \\
\text { of road congestion pressure is pleasant". } \\
\text { att4. Respondents' attitude on the viewpoint that "Vehicle Restrictions' relieve } \\
\text { of road congestion pressure is effective". }\end{array}$ & $\begin{array}{l}\text { Noblet et al. } \\
\text { [23]; Donald et } \\
\text { al. [39]; Liu et } \\
\text { al [44] }\end{array}$ \\
\hline $\begin{array}{l}\text { Subjective } \\
\text { norms }\end{array}$ & SN & $\begin{array}{l}\text { sn1.With Vehicle Restrictions and family's wish to reduce the intention to use } \\
\text { private cars (including taxi), the travel choice of respondents. } \\
\text { sn2. With Vehicle Restrictions and friends' wish to reduce the intention to use } \\
\text { private cars (including taxi), the travel choice of respondents. } \\
\text { sn3. With Vehicle Restrictions and media (including traditional and new media) } \\
\text { wish to reduce the intention to use private cars (including taxi), the travel choice } \\
\text { of respondents. }\end{array}$ & $\begin{array}{l}\text { Jia et al. [26]; } \\
\text { Bamberg et al. } \\
{[45]}\end{array}$ \\
\hline $\begin{array}{l}\text { Perceived } \\
\text { behaviour } \\
\text { control }\end{array}$ & $\mathrm{PBC}$ & $\begin{array}{l}\text { pbc1. With Vehicle Restrictions and faced with frequent travel needs and heavy } \\
\text { traffic, it is easy to get around without a private car (including a taxi) for respon- } \\
\text { dents. } \\
\text { pbc2. With Vehicle Restrictions and faced with frequent travel needs and heavy } \\
\text { traffic, there are many opportunities to travel without a private car (including a } \\
\text { taxi) for respondents. }\end{array}$ & $\begin{array}{l}\text { Noblet et al. } \\
\text { [23]; Chen and } \\
\text { Chao [38]; } \\
\text { Schmidt et al. } \\
{[46]}\end{array}$ \\
\hline $\begin{array}{l}\text { Travel } \\
\text { intention }\end{array}$ & INT & $\begin{array}{l}\text { int1. With Vehicle Restrictions, there is a strong desire of the respondents to } \\
\text { choose other ways to replace private cars (including taxi) for activities (study, } \\
\text { shopping, work, leisure). } \\
\text { int } 2 \text {. With Vehicle Restrictions and suitable conditions, respondents will choose } \\
\text { other ways to replace private cars (including taxi) for activities (study, shopping, } \\
\text { work, leisure). } \\
\text { int3. Respondents will call on their family and friends to choose other ways } \\
\text { and replace private cars (including taxi) for activities (study, shopping, work, } \\
\text { leisure). }\end{array}$ & $\begin{array}{l}\text { Du et al. [10]; } \\
\text { Hoang-Tung } \\
\text { [33]; Bamberg } \\
\text { and Schmidt } \\
{[47]}\end{array}$ \\
\hline $\begin{array}{l}\text { Travel } \\
\text { habits }\end{array}$ & HAB & $\begin{array}{l}\text { hab1. Respondents often travel by car, and it is a strange feeling if they do not. } \\
\text { hab2. Choosing a private car (including taking a taxi) is the respondents' sub- } \\
\text { conscious act. } \\
\text { hab3. Choosing a private car (including taking a taxi) is the respondents' habit } \\
\text { of life. } \\
\text { hab4. Choosing a private car (including taking a taxi) is common for the respon- } \\
\text { dents. }\end{array}$ & $\begin{array}{l}\text { Klöckner and } \\
\text { Matthies [31]; } \\
\text { Verplanken and } \\
\text { Orbell [36]; } \\
\text { Şimşekoğlu et } \\
\text { al. [40] }\end{array}$ \\
\hline $\begin{array}{l}\text { Travel } \\
\text { choice }\end{array}$ & CHOICE & $\begin{array}{l}\text { ch1. On restriction days, the respondents' usual travel mode choice. } \\
\text { ch2. On non-restriction days, the respondents' usual travel mode choice. }\end{array}$ & $\begin{array}{l}\text { Ye and } \\
\text { Titheridge [48] }\end{array}$ \\
\hline
\end{tabular}

norms, and perceived behaviour control, all of which are exogenous latent variables. The second subscale is for travel intention, and the third subscale is for travel habits. The reliability and validity tests show that the Cronbach's alpha value in the total questionnaire is 0.737 , and the standardized value is 0.747 . The standardized Cronbach's alpha values in the three subscales are all greater than 0.9 , indicating the reliability of the entire questionnaire and each subscale. Additionally, all three subscales pass the Kaiser-Meyer-Olkin (KMO) measure and Bartlett's test of sphericity for the principal component analysis. Following the principal component analysis, three principal components were extracted from the scale of TPB and one was extracted from each of the other two subscales. The structure conforms to the theoretical expectation.

Among the effective samples, there are 403 male respondents and 687 female respondents, with a proportion of $44.68 \%$ and $55.32 \%$, respectively. The gender distribution is relatively balanced. As many as $72.75 \%$ of the respondents are between 31 and 50 years of age, belonging to the young and middle-aged groups. The travel demand of young and middle-aged people is generally large and distinctive. In terms of educational level, there are 668 
Dong X, Wang R, Zhou Y. Can Negative Travel Habits Hinder Positive Travel Behavioural Change under Beijing Vehicle...

Table 2 - Reliability and validity test of the questionnaire

\begin{tabular}{|c|c|c|c|c|c|}
\hline Latent variables & Cronbach's $\alpha$ & $\begin{array}{l}\text { Standardized } \\
\text { Cronbach's } \alpha\end{array}$ & Subscales & $\begin{array}{c}\text { Kaiser-Meyer-Olkin } \\
\text { measure }\end{array}$ & $\begin{array}{l}\text { Bartlett's test of } \\
\text { sphericity, Sig. }\end{array}$ \\
\hline Total scale & 0.737 & 0.747 & \multirow[b]{2}{*}{ Scale of TPB } & \multirow[b]{2}{*}{0.862} & \multirow[b]{2}{*}{0.00} \\
\hline Policy attitude & 0.980 & 0.979 & & & \\
\hline Subjective norms & 0.981 & 0.978 & \multirow[b]{2}{*}{$\begin{array}{l}\text { Scale of travel } \\
\text { intention }\end{array}$} & \multirow[b]{2}{*}{0.779} & \multirow[b]{2}{*}{0.00} \\
\hline $\begin{array}{l}\text { Perceived behaviour } \\
\text { control }\end{array}$ & 0.976 & 0.974 & & & \\
\hline Travel intention & 0.970 & 0.968 & \multirow{2}{*}{$\begin{array}{l}\text { Scale of travel } \\
\text { habits }\end{array}$} & \multirow[t]{2}{*}{0.864} & \multirow[t]{2}{*}{0.00} \\
\hline Travel habits & 0.957 & 0.960 & & & \\
\hline
\end{tabular}

Table 3 - Statistics of personal information description

\begin{tabular}{|c|c|c|c|}
\hline Questions & Answers & Numbers & Frequency \\
\hline \multirow{2}{*}{ Gender } & Male & 487 & $44.68 \%$ \\
\hline & Female & 603 & $55.32 \%$ \\
\hline \multirow{7}{*}{ Age } & Under 18 & 18 & $1.65 \%$ \\
\hline & $18 \sim 25$ & 87 & $7.98 \%$ \\
\hline & $26 \sim 30$ & 85 & $7.80 \%$ \\
\hline & $31 \sim 40$ & 383 & $35.14 \%$ \\
\hline & $41 \sim 50$ & 410 & $37.61 \%$ \\
\hline & $51 \sim 60$ & 91 & $8.35 \%$ \\
\hline & Above 60 & 16 & $1.47 \%$ \\
\hline \multirow{3}{*}{ Level of education } & High school and below & 108 & $9.91 \%$ \\
\hline & Undergraduate college & 668 & $61.28 \%$ \\
\hline & Master degree or above & 314 & $28.81 \%$ \\
\hline \multirow{6}{*}{ Occupation } & Administrative staff & 308 & $28.26 \%$ \\
\hline & Enterprise personnel & 421 & $38.62 \%$ \\
\hline & Freelancer & 130 & $11.93 \%$ \\
\hline & Emeritus and retired & 31 & $2.84 \%$ \\
\hline & Students & 45 & $4.13 \%$ \\
\hline & Other & 155 & $14.22 \%$ \\
\hline \multirow{5}{*}{ Monthly income } & Under 10,000 RMB & 513 & $47.06 \%$ \\
\hline & $10,000-30,000 \mathrm{RMB}$ & 430 & $39.45 \%$ \\
\hline & $30,000-50,000 \mathrm{RMB}$ & 93 & $8.53 \%$ \\
\hline & $50,000-70,000 \mathrm{RMB}$ & 25 & $2.29 \%$ \\
\hline & Above $70,000 \mathrm{RMB}$ & 29 & $2.66 \%$ \\
\hline
\end{tabular}


undergraduates and 314 postgraduates, accounting for $61.28 \%$ and $28.81 \%$ of the respective sample. They are primarily distributed throughout the public administration departments and enterprises, accounting for $28.26 \%$ and $38.62 \%$ of the respective sample. The employees with the above two occupations represent the primary commuting groups, which makes it easier to consolidate their own travel choice. As for monthly income, 513 people earn below $10,000 \mathrm{RMB}$, accounting for $47.06 \%$ of the sample, and 430 people earn between 10,000 and $30,000 \mathrm{RMB}$, accounting for $39.45 \%$ of the sample. Both income groups identified above account for $88.35 \%$ of the total sample. The reported average monthly income in Beijing in 2018 was 7,706 yuan according to Beijing's Human Resources and Social Security Bureau, which means that our survey outcome is not far from the actual situation. The permanent population is about 21.7 million according to Beijing Traffic Development Annual Report for 2018 [1]. This means that there are about 7.23 million families in Beijing, as a common family unit usually consists of three people. The number of motor vehicles in Beijing is 5.09 million, which means that about $80 \%$ of families own motor vehicles. According to our survey, 771 households own one private car, accounting for $70.73 \%$, and 135 households own two or more cars, accounting for $12.39 \%$, which is consistent with the authority.

\section{RESULTS}

We used AMOS to analyse the structural equation model. The maximum likelihood estimation method is used first. We then evaluated the overall fitting degree of the model. We tested whether the estimated values of parameters among variables are

Table 4 - The goodness-of-fit statistics significant under the confidence interval. Finally, the relationship between the latent variables was expounded with the standardized path coefficient.

\subsection{Comparison of travel choice}

The empirical results of the model on the restricted days are acceptable. With absolute fitness, the chi-square value is $1,229.974(\mathrm{p}=0.00)$, and the AGFI value is 0.905 . The RMSE value of the residual analysis index is 0.095 , which is generally adaptive. In the case of value-added fitness, the CFI value is 0.960 , the NFI value is 0.956 , and the TLI value is 0.952 . In the case of simple fitness, the PCFI value is 0.798 , and the PNFI value is 0.794 , which is acceptable. The degree of fit of the model on non-restricted days is also strong. The fitness of the model passes the chi-square test, with a value of $1,229.974(\mathrm{p}=0.00)$. The AGFI value is 0.918 , and the RMSE value is 0.083 . In the case of value-added fitness, the CFI value is 0.970 , the NFI value is 0.966 , and the TLI value is 0.963 . In the case of simple fitness, the PCFI value is 0.806 , and the PNFI value is 0.802 .

The results show that the estimate between four latent variables - policy attitude, subjective norms, perceived behaviour control, and travel intention and their corresponding observed variables, as well as the parameter estimates among latent variables, have passed the significance test. All of the paths in the model are accepted, as shown in Table 5, Figures 4 and 5.

On the basis of the standardized path, with travel choice as the only variable changes, policy attitude, subjective norms, and perceived behaviour control on the restricted and non-restricted days have a positive impact on the travel intention, and the path coefficient is the same. The results show that

\begin{tabular}{|c|c|c|c|}
\hline \multicolumn{2}{|c|}{ Fit index of restricted days } & \multicolumn{2}{c||}{ Fit index of non-restricted days } \\
\hline \hline Chi-square & $1,229.974(\mathrm{p}=0.00)$ & Chi-square & $1,229.974(\mathrm{p}=0.00)$ \\
\hline RMSEA & 0.095 & RMSEA & 0.083 \\
\hline AGFI & $0.905(0.9$ and more $)$ & AGFI & $0.918(0.9$ and more $)$ \\
\hline CFI & $0.960(0.9$ and more $)$ & CFI & $0.970(0.9$ and more $)$ \\
\hline NFI & $0.956(0.9$ and more $)$ & NFI & $0.966(0.9$ and more $)$ \\
\hline TLI & $0.952(0.9$ and more $)$ & TLI & $0.963(0.9$ and more $)$ \\
\hline PCFI & $0.798(0.5$ and more $)$ & PCFI & $0.806(0.5$ and more $)$ \\
\hline PNFI & $0.794(0.5$ and more $)$ & PNFI & $0.802(0.5$ and more $)$ \\
\hline
\end{tabular}


Dong X, Wang R, Zhou Y. Can Negative Travel Habits Hinder Positive Travel Behavioural Change under Beijing Vehicle...

Table 5 - The influence of travel intention on travel choice.

\begin{tabular}{|c|c|c|c|c|c|c|c|c|c|c|c|}
\hline & & & \multicolumn{4}{|c|}{ Restricted days } & \multicolumn{4}{|c|}{ Non-restricted days } & \multirow[b]{2}{*}{$\mathrm{P}$} \\
\hline & & & Estimate & S.E. & $\begin{array}{l}\text { Standard } \\
\text { estimate }\end{array}$ & C.R. & Estimate & S.E. & $\begin{array}{l}\text { Standard } \\
\text { estimate }\end{array}$ & C.R. & \\
\hline att1 & $<---$ & ATT & 1.000 & & 0.941 & & 1.000 & & 0.941 & & \\
\hline att2 & $<---$ & ATT & 1.035 & 0.013 & $0.984 * * *$ & 80.672 & 1.035 & 0.013 & $0.984^{* * *}$ & 80.676 & $* * *$ \\
\hline att3 & $<---$ & ATT & 1.019 & 0.015 & $0.957 * * *$ & 69.433 & 1.019 & 0.015 & $0.957^{* * *}$ & 69.433 & $* * *$ \\
\hline att4 & $<---$ & ATT & 1.013 & 0.014 & $0.963 * * *$ & 71.698 & 1.013 & 0.014 & $0.963^{* * *}$ & 71.695 & $* * *$ \\
\hline pbc1 & $<---$ & PBC & 1.000 & & 0.979 & & 1.000 & & 0.979 & & \\
\hline pbc2 & $<---$ & $\mathrm{PBC}$ & 0.983 & 0.012 & $0.974 * * *$ & 79.057 & 0.983 & 0.012 & $0.974^{* * *}$ & 78.947 & $* * *$ \\
\hline $\operatorname{sn} 2$ & $<---$ & SN & 1.029 & 0.011 & $0.987 * * *$ & 95.808 & 1.029 & 0.011 & $0.987^{* * *}$ & 95.802 & $* * *$ \\
\hline sn1 & $<---$ & $\mathrm{SN}$ & 1.005 & 0.012 & $0.969 * * *$ & 83.892 & 1.005 & 0.012 & $0.969^{* * *}$ & 83.892 & $* * *$ \\
\hline int3 & $<---$ & INT & 1.000 & & 0.947 & & 1.000 & & 0.947 & & \\
\hline int2 & $<---$ & INT & 1.003 & 0.013 & $0.968^{* * *}$ & 74.564 & 1.004 & 0.013 & $0.968^{* * *}$ & 74.656 & $* * *$ \\
\hline int1 & $<---$ & INT & 0.997 & 0.014 & $0.953 * * *$ & 69.174 & 0.997 & 0.014 & $0.954^{* * * *}$ & 69.294 & $* * *$ \\
\hline sn3 & $<---$ & $\mathrm{SN}$ & 1.000 & & 0.959 & & 1.000 & & 0.959 & & \\
\hline INT & $<---$ & ATT & 0.297 & 0.022 & $0.306^{* * *}$ & 13.779 & 0.297 & 0.022 & $0.306^{* * * *}$ & 13.717 & $* * *$ \\
\hline INT & $<---$ & $\mathrm{SN}$ & 0.269 & 0.023 & $0.258 * * *$ & 11.729 & 0.268 & 0.023 & $0.257^{* * *}$ & 11.64 & $* * *$ \\
\hline INT & $<---$ & $\mathrm{PBC}$ & 0.437 & 0.021 & $0.459 * * *$ & 21.033 & 0.436 & 0.021 & $0.459^{* * *}$ & 20.923 & $* * *$ \\
\hline $\operatorname{ch} 2$ & $<---$ & INT & & & & & -0.506 & 0.025 & $-0.544^{* * *}$ & -20.578 & $* * *$ \\
\hline ch1 & $<---$ & INT & -0.482 & 0.022 & $-0.577 * * *$ & -22.323 & & & & & \\
\hline
\end{tabular}

Notes: ${ }^{*} p<0.05 ;{ }^{* *} p<0.01 ;{ }^{* * *} p<0.001$

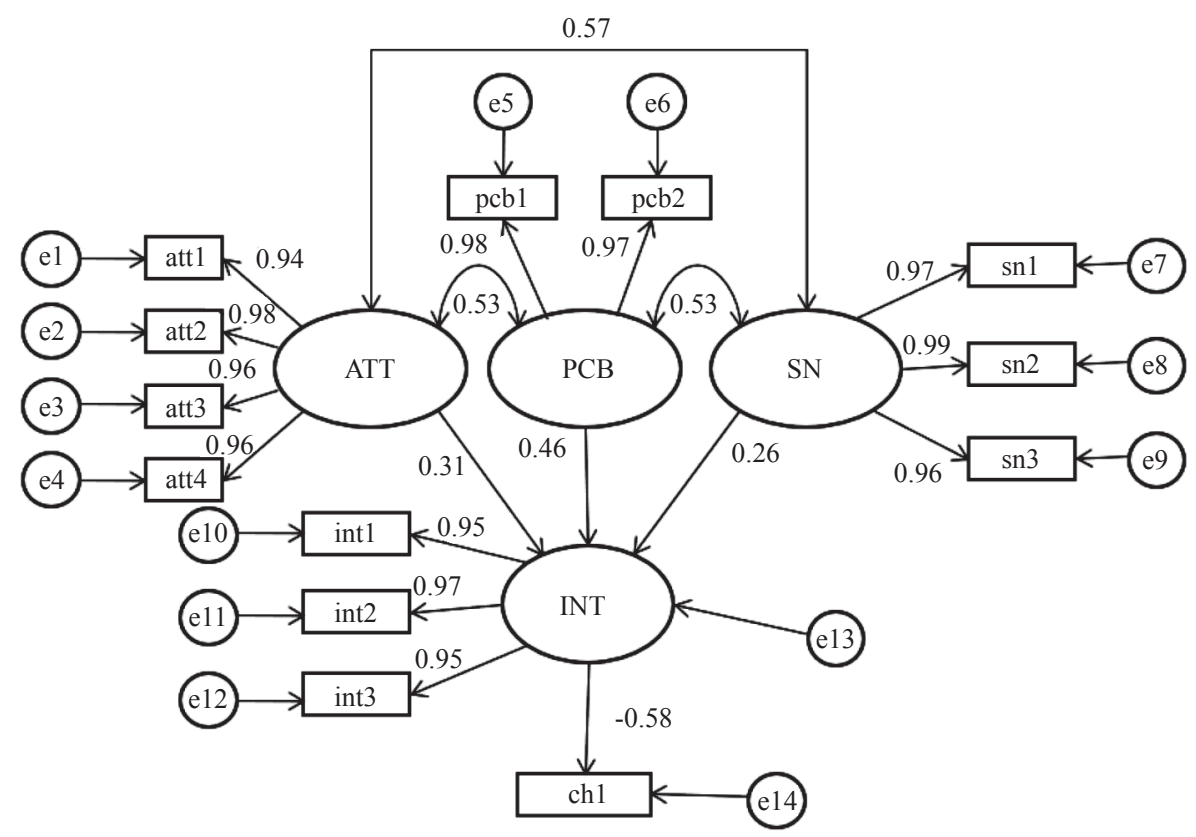

Figure 4 - Standardized path diagram of latent variables and observed variables on restricted days

Vehicle Restrictions have a positive effect on the residents' private car travel choices, which is consistent with the expectation. The policy attitude has a positive impact on travel intention, which can be explained by $31 \%$ of travel choice, supporting H1.1. The positive interpretation of subjective norms on travel intention is $26 \%$, indicating that the external constraints of socialization can affect people's 


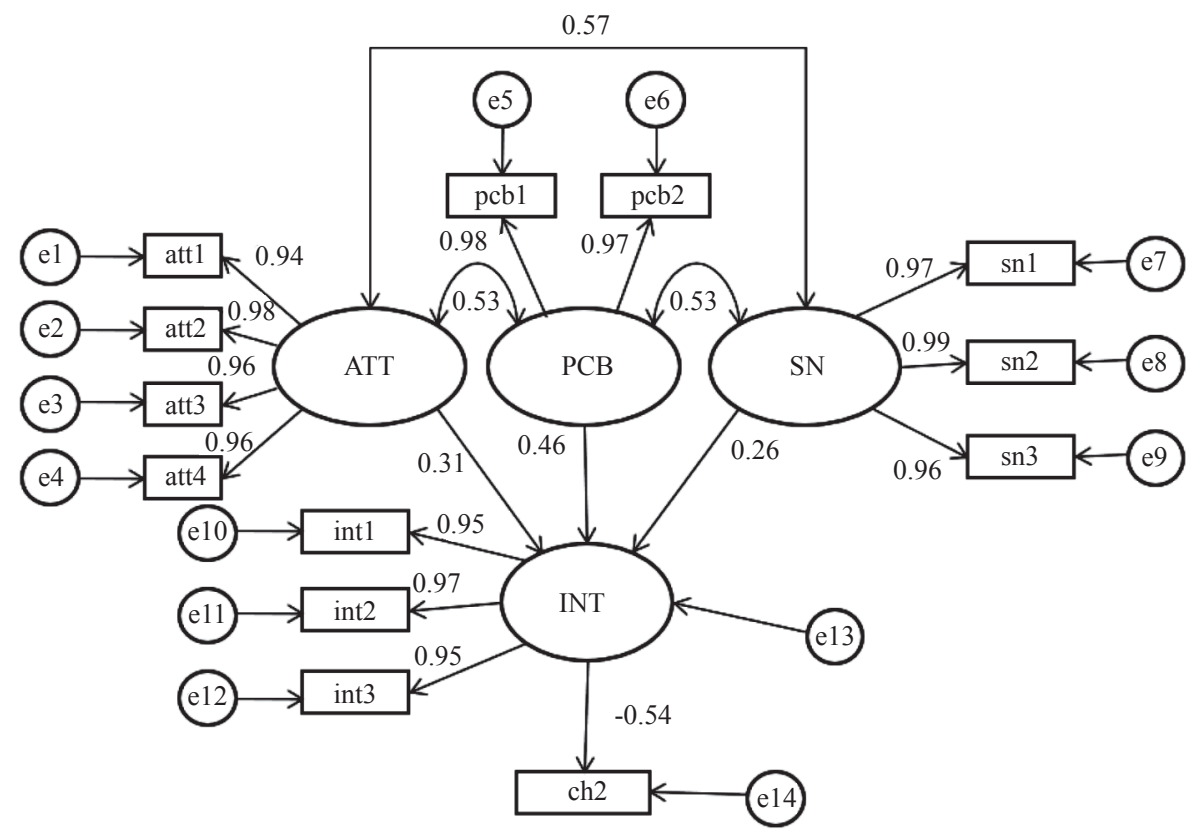

Figure 5 - Standardized path diagram of latent variables and observed variables on non-restricted days

subjective intentions, supporting H1.2. As the exogenous latent variable with the greatest positive influence on the travel intention, perceptive behaviour control can explain $46 \%$ of the results, indicating that the residents can perceive the degree of control over their behaviours, which supports H1.3.

On non-restricted days, travel intention can explain the travel choice of $54 \%$. Comparatively, it can explain the travel choice of $58 \%$ on restricted days, which indicates a negative effect, supporting H1.4. The indirect effect of policy attitude on travel choice on the restricted days is -0.1798 , which indicates that the subjective attitude toward the policy plays a slightly larger role on restricted days than on non-restricted days, which further proves that the policy has a better inhibitory effect on the users' subjective will.

\subsection{Comparison of travel choice mediated by travel habits}

Considering travel habits, the model and data match strongly on the restricted days, as shown in Table 6. The chi-square value is $412.364(\mathrm{p}=0.00)$, and the AGFI, CFI, NFI, and TLI are 0.958, 0.989, 0.985 and 0.987 , respectively. All are higher than 0.9 and meet the acceptability standard. The adjusted indices PCFI and PNFI are 0.807 and 0.804 , respectively, satisfying the standard regulation that exceeds 0.5. The RMSE value of the residual analysis index is 0.050 , which conforms to the standard of less than 0.08 . The model matches strongly on non-restricted days as well. The chi-square value is $387.985(p=0.00)$, the AGFI is 0.960 , the CFI is 0.990 , the NFI is 0.986 , and the TLI index is 0.988 .

Table 6 - The goodness-of-fit statistics

\begin{tabular}{|c|c|c|c||}
\hline \multicolumn{2}{|c|}{ Fit index of restricted days (with travel habits) } & \multicolumn{2}{c||}{ Fit index of non-restricted days (with travel habits) } \\
\hline \hline Chi-square & $412.364(\mathrm{p}=0.00)$ & Chi-square & $387.985(\mathrm{p}=0.00)$ \\
\hline RMSEA & $0.050($ less than 0.08$)$ & RMSEA & 0.083 \\
\hline AGFI & $0.958(0.9$ and more $)$ & AGFI & $0.960(0.9$ and more $)$ \\
\hline CFI & $0.989,(0.9$ and more $)$ & CFI & $0.990(0.9$ and more $)$ \\
\hline NFI & $0.985(0.9$ and more $)$ & NFI & $0.986(0.9$ and more $)$ \\
\hline TLI & $0.987(0.9$ and more $)$ & TLI & $0.988(0.9$ and more $)$ \\
\hline PCFI & $0.807(0.5$ and more $)$ & PCFI & $0.808(0.5$ and more $)$ \\
\hline PNFI & $0.804(0.5$ and more $)$ & PNFI & $0.805(0.5$ and more $)$ \\
\hline
\end{tabular}


Dong X, Wang R, Zhou Y. Can Negative Travel Habits Hinder Positive Travel Behavioural Change under Beijing Vehicle...

Table 7 - The influence of travel habits on travel intention and travel choice

\begin{tabular}{|c|c|c|c|c|c|c|c|c|c|c|c|}
\hline & & & & Restr & ed days & & & Non-res & ted days & & \\
\hline & & & Estimate & S.E. & $\begin{array}{l}\text { Standard } \\
\text { estimate }\end{array}$ & C.R. & Estimate & S.E. & $\begin{array}{l}\text { Standard } \\
\text { estimate }\end{array}$ & C.R. & $\mathrm{P}$ \\
\hline $\mathrm{pbc1}$ & $<---$ & PBC & 1.000 & & 0.979 & & 1.000 & & 0.979 & & \\
\hline pbc2 & $<---$ & PBC & 0.984 & 0.012 & $0.974 * * *$ & 79.041 & 0.984 & 0.012 & $0.974^{* * *}$ & 78.957 & $* * *$ \\
\hline $\operatorname{sn} 2$ & $<---$ & $\mathrm{SN}$ & 1.029 & 0.011 & $0.987 * * *$ & 95.801 & 1.029 & 0.011 & $0.987^{* * *}$ & 95.797 & $* * *$ \\
\hline sn1 & $<---$ & SN & 1.005 & 0.012 & $0.969^{* * *}$ & 83.902 & 1.005 & 0.012 & $0.969^{* * *}$ & 83.898 & $* * *$ \\
\hline int3 & $<---$ & INT & 1.000 & & 0.947 & & 1.000 & & 0.947 & & \\
\hline int2 & $<---$ & INT & 1.003 & 0.013 & $0.968 * * *$ & 74.524 & 1.003 & 0.013 & $0.968^{* * *}$ & 74.653 & $* * *$ \\
\hline int1 & $<--$ & INT & 0.997 & 0.014 & $0.954 * * *$ & 69.284 & 0.997 & 0.014 & $0.954^{* * *}$ & 69.338 & $* * *$ \\
\hline sn3 & $<---$ & SN & 1.000 & & 0.959 & & 1.000 & & 0.959 & & \\
\hline hab1 & $<---$ & HAB & 1.000 & & 0.887 & & 1.000 & & 0.885 & & \\
\hline hab2 & $<---$ & HAB & 1.084 & 0.021 & $0.941 * * *$ & 50.513 & 1.086 & 0.022 & $0.94^{* * *}$ & 50.06 & $* * *$ \\
\hline hab3 & $<---$ & HAB & 1.109 & 0.021 & $0.951 * * *$ & 51.978 & 1.113 & 0.021 & $0.953^{* * *}$ & 51.85 & $* * *$ \\
\hline hab4 & $<---$ & HAB & 1.041 & 0.023 & $0.906^{* * *}$ & 45.926 & 1.045 & 0.023 & $0.907^{* * *}$ & 45.802 & $* * *$ \\
\hline att1 & $<---$ & ATT & 1.000 & & 0.941 & & 1.000 & & 0.941 & & \\
\hline att2 & $<---$ & ATT & 1.035 & 0.013 & $0.984 * * *$ & 80.673 & 1.035 & 0.013 & $0.984^{* * *}$ & 80.677 & $* * *$ \\
\hline att3 & $<---$ & ATT & 1.019 & 0.015 & $0.957 * * *$ & 69.432 & 1.019 & 0.015 & $0.957^{* * *}$ & 69.43 & $* * *$ \\
\hline att4 & $<---$ & ATT & 1.013 & 0.014 & $0.963 * * *$ & 71.699 & 1.013 & 0.014 & $0.963^{* * *}$ & 71.697 & $* * *$ \\
\hline INT & $<---$ & ATT & 0.297 & 0.022 & $0.307 * * *$ & 13.818 & 0.297 & 0.022 & $0.306^{* * *}$ & 13.762 & $* * *$ \\
\hline INT & $<---$ & SN & 0.27 & 0.023 & $0.259 * * *$ & 11.765 & 0.268 & 0.023 & $0.257^{* * *}$ & 11.658 & $* * *$ \\
\hline INT & $<---$ & PBC & 0.436 & 0.021 & $0.458^{* * *}$ & 21.017 & 0.436 & 0.021 & $0.458^{* * *}$ & 20.933 & $* * *$ \\
\hline HAB & $<---$ & INT & -0.627 & 0.03 & $-0.589 * * *$ & -21.219 & -0.625 & 0.03 & $-0.589^{* * *}$ & -21.184 & $* * *$ \\
\hline $\operatorname{ch} 2$ & $<---$ & INT & & & & & -0.180 & 0.025 & $-0.193^{* * *}$ & -7.129 & $* * *$ \\
\hline $\operatorname{ch} 2$ & $<---$ & HAB & & & & & 0.523 & 0.025 & $0.596^{* * *}$ & 20.833 & $* * *$ \\
\hline $\operatorname{ch} 1$ & $<---$ & INT & -0.327 & 0.025 & $-0.391 * * *$ & -12.862 & & & & & \\
\hline ch1 & $<---$ & HAB & 0.247 & 0.024 & $0.314^{* * *}$ & 10.227 & & & & & \\
\hline
\end{tabular}

Notes: ${ }^{*} p<0.05 ;{ }^{* *} p<0.01 ;{ }^{* * *} p<0.001$

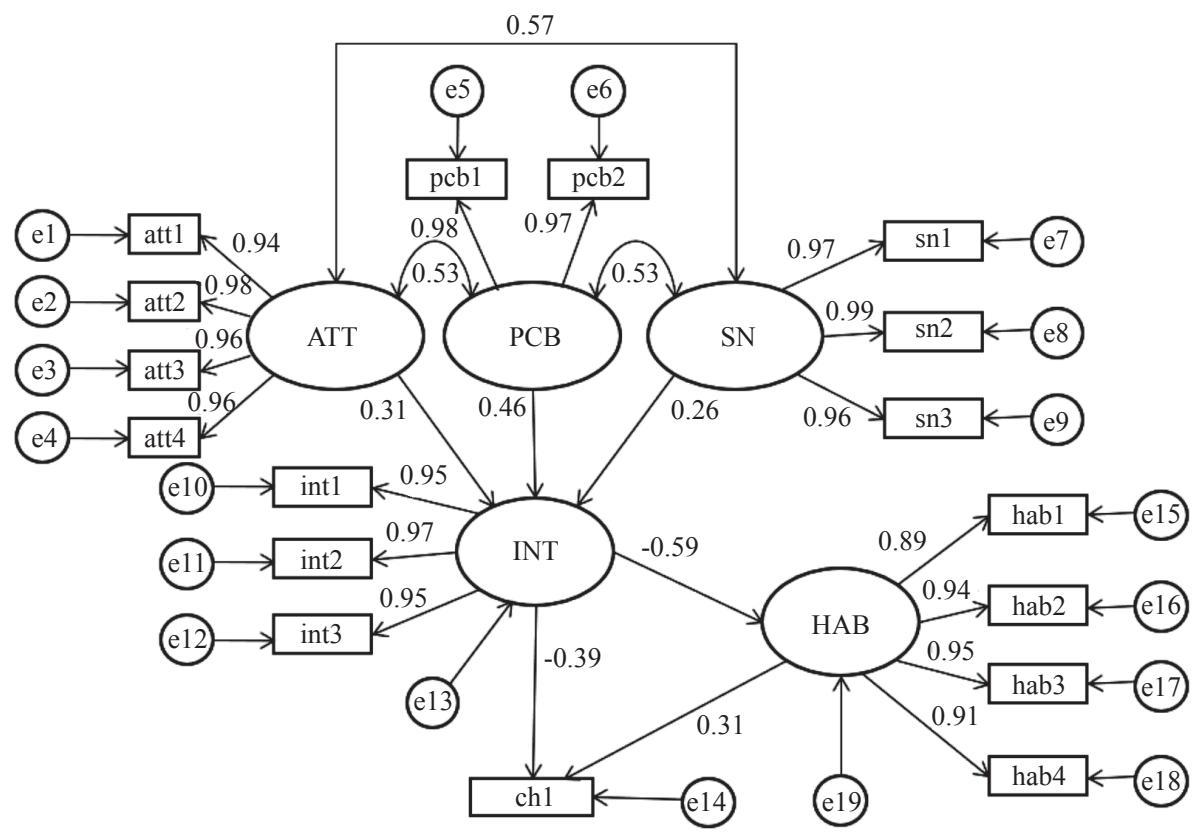

Figure 6 - Standardized path diagram of latent variables and observed variables on restricted days, mediated by travel habits 


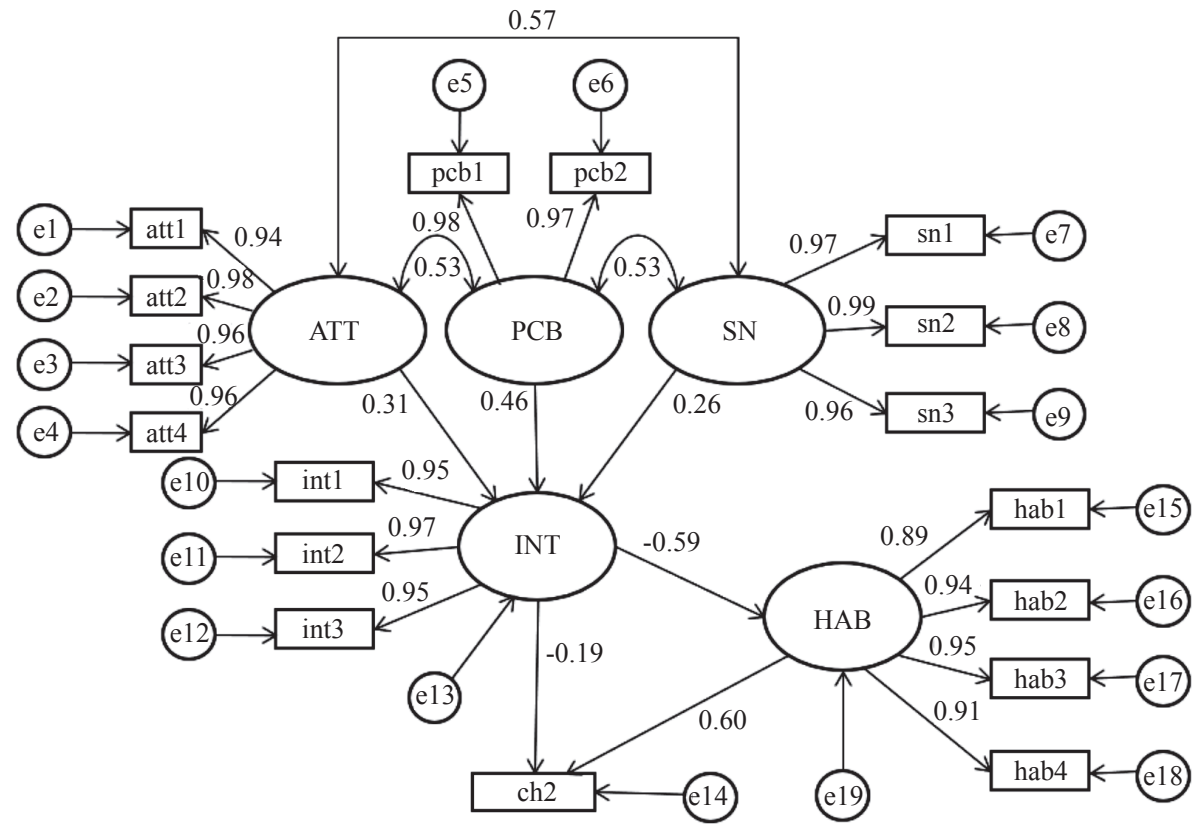

Figure 7 - Standardized path diagram of latent variables and observed variables on non-restricted days, mediated by travel habits

All meet the acceptable standard. The PCFI and PNFI are 0.808 and 0.805 , respectively, exceeding the standard of 0.5 . The RMSE is 0.048 , which meets the requirement of less than 0.08 .

These results demonstrate that with travel habits, the observed indicators can adequately depict the corresponding four latent variables. The standardized estimated values are all greater than 0.8 and pass the significance test. The p-value is less than 0.01. At the same time, the parameter estimation among all latent variables passes the test. Figure 6 shows the standardized path with travel habits in two scenarios.

Compared with the results in Section 5.1, the relationship among policy attitude, subjective norms, and perceptive control are still consistent, as shown in Table 7, Figures 6 and 7. This finding reveals that residents have not changed their attitude, subjective norms, and perceived behaviour control. The only change is in the path coefficient between subjective intention and travel choice. The influential effect of converting to public transport changes from -0.54 to -0.19 on non-restricted days, with the absolute value decreasing, indicating that with travel habits, the interpretation degree of travel choice by travel intention decreases significantly. However, travel habits demonstrate a positive effect on travel choice, which can explain $60 \%$ of people's actual travel behaviour. When private car travel becomes inertial thinking, the residents are more likely to succumb to the travel habit on non-restricted days, supporting
H2. On restricted days, the coefficient changes from 0.58 to 0.39 , and the absolute value is reduced, but this is no more obvious than that of non-restricted days. Similarly, private car (or taking a taxi) travel habits affect people's travel choice behaviour in a positive manner, but only by $31 \%$, which shrinks by $29 \%$ when compared with non-restricted days. This demonstrates that the policy has a more active guiding effect on the residents' travel choices when they have developed a habit of using private cars on restricted days. In the context of long-term Vehicle Restrictions, travel habits show a negative intermediary effect between travel intention and travel choice, and they play a role in blocking. On restricted days, the effect of Vehicle Restrictions on the residents' travel choice of public transportation remains the same (direct effects - 0.39 , and the indirect effect $-0.59 * 0.31$, the total is 0.57 , as H.3 hypothesizes).

\subsection{Income grouping scenario on restricted days}

To investigate the role of income in the residents' travel choice, the samples were divided into groups according to their income as follows: the high-income group earning more than 30,000 RMB a month, and the low-income group earning less than 30,000 RMB a month. By grouping the model fitting, we tested for differences in how travel habits influence the travel choice in different groups on 
Dong X, Wang R, Zhou Y. Can Negative Travel Habits Hinder Positive Travel Behavioural Change under Beijing Vehicle...

Table 8 - The goodness-of-fit statistics

\begin{tabular}{||c|c|c|c||}
\hline \multicolumn{2}{|c|}{ Fit index of restricted days (low-income group) } & \multicolumn{2}{c||}{ Fit index of restricted days (high-income group) } \\
\hline \hline Chi-square & $374.498(\mathrm{p}=0.00)$ & Chi-square & $194.772(\mathrm{p}=0.00)$ \\
\hline RMSEA & $0.048($ less than 0.08$)$ & RMSEA & 0.067 (less than 0.08) \\
\hline AGFI & $0.943(0.9$ and more $)$ & AGFI & $0.831(0.9$ and more $)$ \\
\hline CFI & $0.989(0.9$ and more $)$ & CFI & $0.978(0.9$ and more $)$ \\
\hline NFI & $0.985(0.9$ and more $)$ & NFI & $0.946(0.9$ and more $)$ \\
\hline TLI & $0.988(0.9$ and more $)$ & TLI & $0.974(0.9$ and more $)$ \\
\hline PCFI & $0.851(0.5$ and more $)$ & PCFI & $0.841(0.5$ and more $)$ \\
\hline PNFI & $0.847(0.5$ and more $)$ & PNFI & $0.814(0.5$ and more $)$ \\
\hline
\end{tabular}

restricted days, as shown in Table 8. In the low-income group, the chi-square value is 374.498 $(\mathrm{p}=0.00)$, and the AGFI, CFI, NFI, and TLI are $0.943,0.989,0.985$, and 0.988 , respectively. In the high-income group, the chi-square value is 194.772 , and the CFI, NFI, and TLI are 0.978, 0.946, and
0.974 , respectively. On the whole, the fitness indices and residual analysis indices of the two models after grouping all to meet the standards - and the structural equation model fitting of the two groups perform well as a whole. The standardized figure of empirical output is shown in Figures 8 and 9.

Table 9 - The influence of travel habits on travel intention and travel choice on restricted days

\begin{tabular}{|c|c|c|c|c|c|c|c|c|c|c|c|c|}
\hline & \multicolumn{5}{|c|}{ Low-income group } & \multicolumn{5}{|c|}{ High-income group } \\
\hline & & & Estimate & S.E. & $\begin{array}{l}\text { Standard } \\
\text { estimate }\end{array}$ & C.R. & $\mathrm{P}$ & Estimate & S.E. & $\begin{array}{l}\text { Standard } \\
\text { estimate }\end{array}$ & C.R. & $\mathrm{P}$ \\
\hline pbc1 & $<---$ & $\mathrm{PBC}$ & 1.000 & & 0.980 & & & 1.000 & & 0.976 & & \\
\hline $\mathrm{pbc} 2$ & $<---$ & $\mathrm{PBC}$ & 0.978 & 0.013 & 0.972 & 73.365 & $* * *$ & 1.011 & 0.034 & 0.979 & 29.534 & $* * *$ \\
\hline $\operatorname{sn} 2$ & $<---$ & $\mathrm{SN}$ & 1.034 & 0.011 & 0.988 & 91.692 & $* * *$ & 0.994 & 0.034 & 0.983 & 29.605 & $* * *$ \\
\hline sn1 & $<---$ & $\mathrm{SN}$ & 1.014 & 0.012 & 0.976 & 83.519 & $* * *$ & 0.939 & 0.043 & 0.917 & 21.812 & $* * *$ \\
\hline int3 & $<---$ & INT & 1.000 & & 0.945 & & & 1.000 & & 0.963 & & \\
\hline int2 & $<---$ & INT & 0.999 & 0.015 & 0.965 & 67.48 & $* * *$ & 1.036 & 0.027 & 0.992 & 37.703 & $* * *$ \\
\hline int1 & $<---$ & INT & 1.003 & 0.016 & 0.956 & 64.394 & $* * *$ & 0.946 & 0.037 & 0.936 & 25.596 & $* * *$ \\
\hline sn3 & $<---$ & $\mathrm{SN}$ & 1.000 & & 0.961 & & & 1.000 & & 0.95 & & \\
\hline hab1 & $<---$ & HAB & 1.000 & & 0.886 & & & 1.000 & & 0.893 & & \\
\hline hab2 & $<---$ & HAB & 1.081 & 0.023 & 0.941 & 46.884 & $* * *$ & 1.115 & 0.059 & 0.942 & 18.774 & $* * *$ \\
\hline hab3 & $<---$ & HAB & 1.11 & 0.023 & 0.953 & 48.462 & $* * *$ & 1.104 & 0.06 & 0.937 & 18.538 & $* * *$ \\
\hline hab4 & $<---$ & HAB & 1.051 & 0.024 & 0.91 & 43.055 & $* * *$ & 0.982 & 0.062 & 0.878 & 15.772 & $* * *$ \\
\hline att1 & $<---$ & ATT & 1.000 & & 0.945 & & & 1.000 & & 0.919 & & \\
\hline att2 & $<---$ & ATT & 1.034 & 0.013 & 0.984 & 77.348 & $* * *$ & 1.04 & 0.042 & 0.978 & 24.706 & $* * *$ \\
\hline att3 & $<---$ & ATT & 1.021 & 0.015 & 0.958 & 66.338 & $* * *$ & 1.008 & 0.047 & 0.945 & 21.561 & $* * *$ \\
\hline att4 & $<---$ & ATT & 1.012 & 0.015 & 0.964 & 68.399 & $* * *$ & 1.020 & 0.045 & 0.956 & 22.529 & $* * *$ \\
\hline INT & $<---$ & ATT & 0.287 & 0.023 & 0.296 & 12.269 & $* * *$ & 0.381 & 0.057 & 0.393 & 6.732 & $* * *$ \\
\hline INT & $<---$ & $\mathrm{SN}$ & 0.285 & 0.025 & 0.273 & 11.569 & $* * *$ & 0.144 & 0.062 & 0.140 & 2.335 & 0.020 \\
\hline INT & $<---$ & PBC & 0.429 & 0.023 & 0.451 & 18.971 & $* * *$ & 0.482 & 0.053 & 0.508 & 9.100 & $* * *$ \\
\hline HAB & $<---$ & INT & -0.621 & 0.032 & -0.586 & -19.585 & $* * *$ & -0.648 & 0.08 & -0.598 & -8.056 & $* * *$ \\
\hline $\operatorname{ch} 1$ & $<---$ & INT & -0.335 & 0.027 & -0.404 & -12.37 & $* * *$ & -0.249 & 0.073 & -0.291 & -3.439 & $* * *$ \\
\hline $\mathrm{ch} 1$ & $<---$ & HAB & 0.238 & 0.026 & 0.304 & 9.247 & $* * *$ & 0.307 & 0.069 & 0.388 & 4.458 & $* * *$ \\
\hline
\end{tabular}




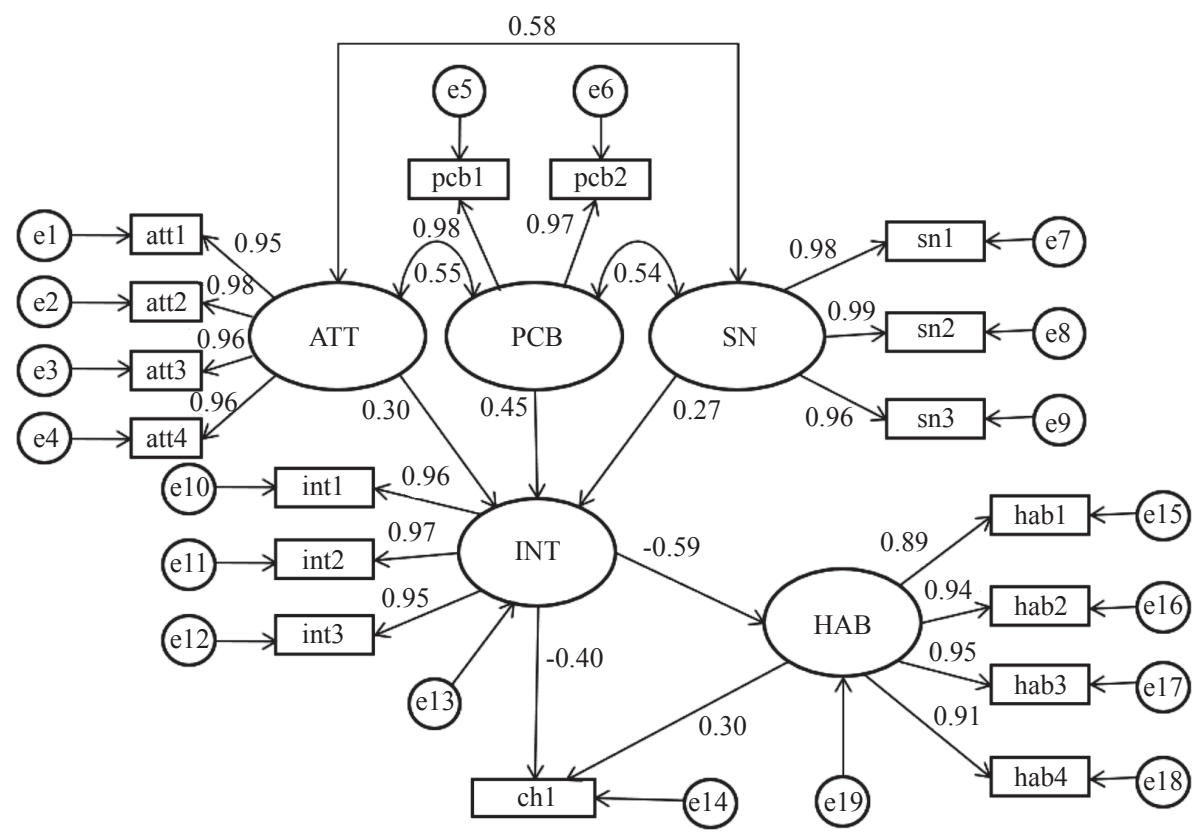

Figure 8 - Standardized path diagram of latent and observed variables for the low-income group

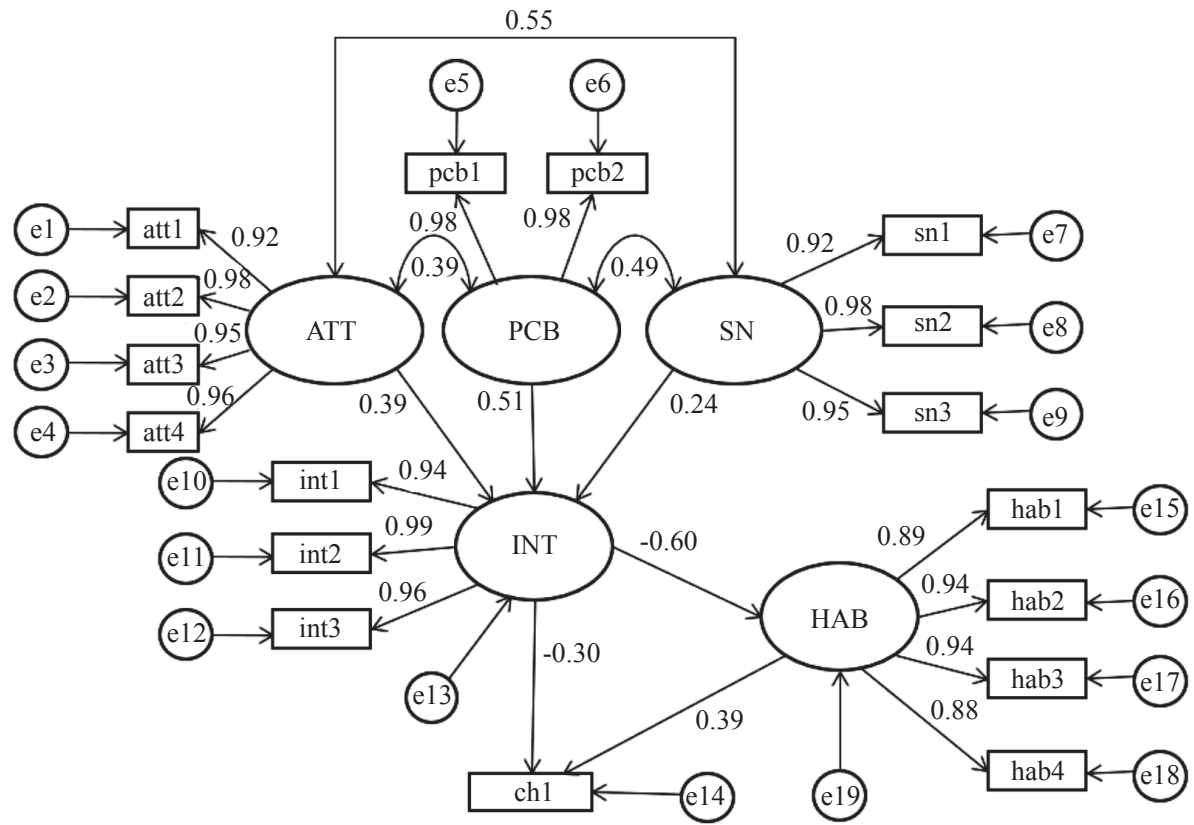

Figure 9 - Standardized path diagram of latent variables and observed variables for the high-income group

All latent variables of low-income group samples and parameter estimation between latent variables and observable variables pass the significance test. As shown in Figure 8, the explanation of policy attitude, subjective norm, and perceived behavioural control for travel intention change only a little, compared with Figure 5, which depicts all of the samples. The influence of subjective intention on travel choice is negative at $40 \%$, and the influence of travel habits on travel choice is positive at
$30 \%$ on restricted days. The overall impact of Vehicle Restrictions on travel is identical, with a total effect of 0.57 .

Each latent variable of the high-income group and parameter estimation between the latent variable and the observable variable also pass the significance test, as shown in Figure 9. In the high-income group, the policy attitude and the perceived behaviour control have a stronger influence over travel intention, with the explanation degree at $39 \%$ 
and $51 \%$, respectively. The role of subjective norms on travel intention exhibits a slight decline, and the degree is $24 \%$. Travel habits of the high-income group explain their travel choice as 39\% higher than that of the low-income group (30\%). This finding reveals that the high-income group is more inclined to choose private cars (including taxis) because they have greater economic power to spend more wealth on the use and purchase of cars and the pursuit of more comfortable travel experience. Simultaneously, they can save time to create more value, which causes travel habits to dominate their travel choice much more frequently. As a result of the limitation of the consumption ability, the low-income group, constrained by Vehicle Restrictions, are more likely to choose economical vehicles, because not all of them can afford private modes. They are more likely to be affected by conscious decision-making under the policy constraint, supporting $\mathrm{H} 4$.

To summarize, travel habits have the effect of solidification. It is difficult for residents with private car travel habits to change their original travel mode. The direct influence of habits dominates the travel choice, and the direct influence of travel intention under Vehicle Restrictions is weakened. With regard to long-term implementation, the continuous stimulus and restraint effect of the policy solidifies the relationship between travel intention and habits, thus indirectly affecting the travel choice, forcing residents to adjust their original habits. When adjusted habits have a greater advantage, the stimulus-restraint effect of the policies becomes apparent. Additionally, on restricted days with policy constraints more powerfully in place, the intensity of habit adjustment among different groups is also different. The private car travel habits of the high-income group or private car owners are relatively stable, while the low-income group, or people without private cars, are more sensitive to the policies, and as a result, their travel habits are more strongly influenced by the mentioned policies.

\section{DISCUSSION}

This study focuses on the 12-year implementation of Vehicle Restrictions in Beijing. Based on $\mathrm{TPB}$, we added travel habits as an intermediary variable and discussed the change in the residents' travel behaviour with regard to private cars (including taxis) under the TDM policies.
We treated the policy attitude as an indicator of comprehensive attitudes toward Vehicle Restrictions, which can affect the residents' travel intention and further affect their travel choice. This finding is inconsistent with the path of attitudes and habits affected by the limiting policies documented in some of the relevant extant literature [44]. While research supporting the positive effect of Vehicle Restrictions still indicates that it can improve the use of public transport, private cars face different acceptance levels between public policy limitations and private restrictions $[49,50]$. Similarly, our empirical work shows that the subjective norms and perceived behavioural control will positively affect people's conversion of travel modes, demonstrating a stronger effect under perceived behavioural control. In other words, the residents' intentions are primarily subject to their degree of control over certain things, and their travel intention toward non-private vehicles negatively affects the use of private cars on the restricted days [10, 25, 38, 39].

In this study, we further verified the negative effect of the residents' inherent habits toward Vehicle Restrictions with the help of new variables, including travel habits. Travellers with the habit of using private cars may rely on their awareness, derived from their habits, and it is difficult for them to be affected by changes in external conditions and situations, which is consistent with some findings on the damping effect of travel habits. However, the negative indirect effect we have identified between travel intention and travel choice exhibits certain differences with the existing research, which confirms the parallel influence of the habits on travel intention and choice simultaneously [40,41]. On this basis, the basic model was extended and it was concluded that Vehicle Restrictions have a certain guiding effect on the residents' travel choice, regardless of the restricted or non-restricted days, with or without the mediated effect of travel habits. This indicates that the residents accustomed to private cars will follow the restriction policies on the restricted days. Our further research by grouping shows that the binding force of the limiting policies is weak among the high-income group, while the low-income group is more sensitive to the policy. Many scholars believe that the travellers are sensitive to the congestion charge, and the implementation of the congestion charge will change their travel habits [15]. However, as the empirical logic demonstrated above, the change in travel habits may be more dependent on 
the time effect and policy constraints rather than the monetary costs of policies. The long-term and stable nature of Vehicle Restrictions may be an effective means of changing people's inherent habits, which also accounts for why we focus on those 12year implementation policies.

\section{CONCLUSION}

In this paper, the mediating role of habits between travel intention and travel choice is investigated in the context of restriction policies in Beijing. First, the study has found that generally, Vehicle Restrictions in Beijing play a positive role in modifying the residents' travel choices. On the one hand, the policy has demonstrated negative guidance in terms of private car use. On the other hand, it positively compels residents to take more public transportation. This indicates that vehicle restrictions have served as a useful authoritative tool to control urban traffic congestion. Second, as a continuation of the original thinking mode, when interpreted as a fixed automatic stimulation of consciousness, the habit can be regarded as an opportunity cost that obstructs new choices. In this study, the solidification and blocking effects of travel habits are verified. More specifically, the residents with the habit of using private cars are more inclined to use private cars, regardless of any restriction policies. The third aspect of the study centres on the positive inhibitory effect of the limiting policies on habits. The residents with the habit of using private cars (including taxis) tend to use private cars, but they are still affected by Vehicle Restrictions. The probability of taking private cars (or taking taxis) on restricted days is reduced. Fourth, the guiding effect of the policies on the high-income group is significantly weaker than that of the low-income group. Significantly, the high-income group with the habit of using private cars still tend to take private cars on restricted days, indicating that they are less sensitive to the restrictions than the low-income group.

Our results indicate that people's travel habits have a certain weakening effect on the implementation of the policy. Residents' travel choices tend to be fixed, and it is difficult for people who often travel by private car to change their original habits under the restriction policy, which of course violates the goal of the said policy. The existence of habits has caused certain interference with the role of private car driving restrictions. In other words, people's private car travel habits have reduced the efficiency of driving restrictions. It has been 12 years since the implemen- tation of the traffic restriction policy in Beijing. To some extent, Vehicle Restrictions have demonstrated an effect on traffic relief, although the current congestion situation in Beijing is still relatively serious. People travel more frequently on weekends due to the odd-even license plate restrictions on weekdays. Overall, people's private car travel behaviour has not changed much, but it has increased the urban traffic burden on the weekends. In 2018, Beijing introduced a new round of differentiated parking pricing policies. The new pricing standard is more refined. On the one hand, it increases the pricing level of price zones, and on the other hand, it implements differentiated pricing based on the parking time. The authorities in Beijing hope to strengthen the role of the traffic restrictions through stricter parking price control. Under the dual policy, people's inherent travel habits did not appear to have changed significantly. The charging policy has a certain impact on price-sensitive low-income groups, whose private car trips may be reduced, but the short-term effect of the policy is not obvious for all of the traveling population in Beijing. A relevant question is whether the charging policy or Vehicle Restrictions, which are seemingly fair, are in fact unfair considering the residents' avoidance of the policies. The low-income group is the effective subject of the restriction policies. Accordingly, the charging policy may have a kind of "Robin Hood" effect. Similarly, Vehicle Restrictions also imply distributional effects.

There are three limitations to our work. First, the sample data are cross-section data in nature, which lacks dynamics. Psychological factors, such as policy attitude, often fluctuate with time, but the questionnaire is only related to the respondents' feelings at a certain static point. Second, the measurement method of travel habits may be subjective. We cannot judge whether the residents in Beijing maintain their previous habits under the long duration of the repetition experiments, for which further studies may be conducted on the repetition frequency sufficient for habits.

\section{ACKNOWLEDGEMENT}

This research was supported by the National Social Science Foundation of China (No. 15BJY054).

董笑，硕士 ${ }^{1}$

电子邮箱: 981666907@qq.com

王若雅, 博士研究生 ${ }^{1}$

电子邮箱: zoeywry@126.com 
周耀东, 博士 1

电子邮箱: ydzhou@bjtu.edu.cn

1 北京交通大学经济管理学院

中国北京市海淀区上园村3号

\section{消极的出行习惯是否阻碍出行行为改变一 以北京为例}

\section{摘要}

随着大城市的快速发展，面临工作和生活压力, 人们往往会固化自身的交通方式，形成个人出行习 惯，这对城市交通管理提出了更高要求。基于修正 的计划行为理论, 本文采用结构方程方法研究北京 地区居民的出行行为, 发现在尾号限行政策下, 政 策态度、感知行为控制和主观规范综合影响居民出 行意愿。面对限行政策的要求, 不拥有私家车的居 民采用私家车以外其他交通方式的意愿更强。当考 虑出行习惯的中介作用时，限行政策的影响有所减 弱, 私家车出行习惯会抵制居民改变其出行选择。 与低收入人群相比, 高收入人群的出行习惯表现得 更稳定。一般来说, 居民的收入越高, 对私家车的 依赖程度越高。整体来看, 出行习惯一定程度上削 弱了限行政策的实施效果。交通管理政策的制定应 明确逐步改变居民出行习惯的重要性。

\section{关键词}

出行选择; 出行习惯; 计划行为理

论; 结构方程模型; 限行政策

\section{REFERENCES}

[1] Beijing Traffic Development Annual Report. Beijing Transport Institute; 2018.

[2] Beck MJ, Rose JM, Hensher DA. Environmental attitudes and emissions charging: An example of policy implications for vehicle choice. Transportation Research Part A: Policy and Practice. 2013;50: 171-182.

[3] Lu M, Sun C, Zheng S. Congestion and pollution consequences of driving-to-school trips: A case study in Beijing. Transportation Research Part D: Transport and Environment. 2017;50: 280-291.

[4] Mohamed M, Bromfield NF. Attitudes, driving behaviour, and accident involvement among young male drivers in Saudi Arabia. Transportation Research Part F: Traffic Psychology and Behaviour. 2017;47: 59-71.

[5] Víctor C, Juan DO. Restricting the use of cars by license plate numbers: A misguided urban transport policy. Dyna Rev.fac.nac.minas. 2014;81(188): 75-82.

[6] Wen H, Sun J, Zhang X. Study on traffic congestion patterns of large city in China taking Beijing as an example. Procedia - Social and Behavioural Sciences. 2014;138: 482-491.

[7] Liu Y, Ji YJ, Shi ZB, He BH, Liu QY. Investigating the effect of the spatial relationship between home, workplace and school on parental chauffeurs' daily travel mode choice. Transport Policy. 2018;69: 78-87.

[8] Wang L, Xu J, Qin P. Will a driving restriction policy reduce car trips? - The case study of Beijing, China. Transportation Research Part A: Policy and Practice. 2014;67: 279-290.

[9] Viard VB, Fu S. The effect of Beijing's driving restrictions on pollution and economic activity. Journal of Public Economics. 2015;125: 98-115.

[10] Du HB, Liu DY, Sovacool BK, Wang YR, Ma SF, Li R. Who buys new energy vehicles in China? Assessing social-psychological predictors of purchasing awareness, intention, and policy. Transportation Research Part F: Traffic Psychology and Behaviour. 2018;58: 56-69.

[11] Verplanken B, Aarts H. Habit, attitude, and planned behaviour: is habit an empty constructor an interesting case of goal-directed automaticity? European Review of Social Psychology. 1999;10(1): 101-134.

[12] Wood W. A new look at habits and the habit-goal interface. Psychological Review. 2007;114(4): 843-863.

[13] Wood W, Neal DT. The habitual consumer. Journal of Consumer Psychology. 2009;19(4): 579-592.

[14] Bonnel P. Urban car policy in Europe. Transport Policy. 1995;2(2): 83-95.

[15] Albert G, Mahalel D. Congestion tolls and parking fees: A comparison of the potential effect on travel behaviour. Transport Policy. 2006;13(6): 496-502.

[16] Habibian M, Kermanshah M. Coping with congestion: Understanding the role of simultaneous transportation demand management policies on commuters. Transport Policy. 2013;30: 229-237.

[17] Cavallaro F, Giaretta F, Nocera S. The potential of road pricing schemes to reduce carbon emissions. Transport Policy. 2017;67: 85-92.

[18] Schwanen T, Dieleman FM, Dijst M. Travel behaviour in Dutch monocentric and policentric urban systems. Journal of Transport Geography. 2001;9(3): 173-186.

[19] Kingham S, Dickinson J, Copsey S. Travelling to work: Will people move out of their cars. Transport Policy. 2001;8(2): 151-160.

[20] Bhat CR, Sen S, Eluru N. The impact of demographics, built environment attributes, vehicle characteristics, and gasoline prices on household vehicle holdings and use. Transportation Research Part B: Methodological. 2009;43(1): 1-18.

[21] Ding C, Wang Y, Tang T, Mishra S, Liu C. Joint analysis of the spatial impacts of built environment on car ownership and travel mode choice. Transportation Research Part D: Transport and Environment. 2018;60: 28-40.

[22] Hine J, Scott J. Seamless, accessible travel: Users' views of the public transport journey and interchange. Transport Policy. 2000;7(3): 217-226.

[23] Noblet CL, Thøgersen J, Teisl MF. Who attempts to drive less in new England? Transportation Research Part F: Traffic Psychology and Behaviour. 2014;23: 69-80.

[24] Lind HB, Nordfjærn T, Jørgensen SH, Rundmo T. The value-belief-norm theory, personal norms and sustainable travel mode choice in urban areas. Journal of Environmental Psychology. 2015;44: 119-125.

[25] Lo SH, Breukelen GJP, Peters GJY, Kok G. Commuting travel mode choice among office workers: Comparing an extended theory of planned behaviour model between regions and organizational sectors. Travel Behaviour and Society. 2015;4: 1-10. 
[26] Jia N, Li LY, Ling S, Ma SF, Yao W. Influence of attitudinal and low-carbon factors on behavioural intention of commuting mode choice - A cross-city study in China. Transportation Research Part A: Policy and Practice. 2018;111: 108-118.

[27] Stark J, Berger WJ, HöSsinger R. The effectiveness of an intervention to promote active travel modes in early adolescence. Transportation Research Part F: Traffic Psychology and Behaviour. 2018;55: 389-402.

[28] Aarts H, Dijksterhuis AP. The automatic activation of goal-directed behaviour: The case of travel habit. Journal of Environmental Psychology. 2000;20(1): 75-82.

[29] Bamberg S. Chapter 9 Understanding and promoting bicycle use - Insights from psychological research. In: Parkin J. (ed.) Cycling and Sustainability (Transport and Sustainability, Vol. 1). Bingley, UK: Emerald Group Publishing Limited; 2012. p. 219-246.

[30] Fujii S, Gärling T. Development of script-based travel mode choice after forced change. Transportation Research Part F: Traffic Psychology and Behaviour. 2003;6(2): 117-124.

[31] Klöckner CA, Matthies E. How habits interfere with norm-directed behaviour: A normative decision-making model for travel mode choice. Journal of Environmental Psychology. 2004;24(3): 319-327.

[32] Thomas GO, Walker I. Users of different travel modes differ in journey satisfaction and habit strength but not environmental worldviews: A large-scale survey of drivers, walkers, bicyclists and bus users commuting to a UK university. Transportation Research Part F: Traffic Psychology and Behaviour. 2015;34: 86-93.

[33] Hoang-Tung N, Kojima A, Kubota H. Transformation from intentions to habits in travel behaviour: An awareness of a mediated form of intention. Transportation Research Part F: Traffic Psychology and Behaviour. 2017;49: 226-235.

[34] Setiawan R, Santosa W, Sjafruddin A. The Effect of Students' Car Access and Car use Habits on Student Behaviour to Reduce using Cars for Traveling to Campus. Procedia Engineering. 2017;171(7): 1454-1462.

[35] Lanken B, Aarts H, Knippenberg AV, Knippenberg CV. Attitude versus general habit: Antecedents of travel mode choice. Journal of Applied Social Psychology. 1994;24(4): 285-300.

[36] Verplanken B, Orbell S. Reflections on past behaviour: A self-report index of habit strength1. Journal of Applied Social Psychology. 2003;33(6): 1313-1330.

[37] Li ZY, L RM, Wang XK, Pan S. Effects of vehicle restriction policies: Analysis using license plate recognition data in Langfang, China. Transportation Research Part A: Policy and Practice. 2018;118: 89-103.

[38] Chen CF, Chao WH. Habitual or reasoned? Using the theory of planned behaviour, technology acceptance model, and habit to examine switching intentions toward public transit. Transportation Research Part F: Traffic Psychology and Behaviour. 2011;14(2): 128-137.

[39] Donald IJ, Cooper SR, Conchie SM. An extended theory of planned behaviour model of the psychological factors affecting commuters - Transport mode use. Journal of Environmental Psychology. 2014;40: 39-48.

[40] Şimşekoğlu Ö, Trond N, Torbjørn R. The role of attitudes, transport priorities, and car use habit for travel mode use and intentions to use public transportation in an urban Norwegian public. Transport Policy. 2015;42: 113-120.

[41] Klöckner CA, Friedrichsmeier T. A multi-level approach to travel mode choice - How person characteristics and situation specific aspects determine car use in a student sample. Transportation Research Part F: Traffic Psychology and Behaviour. 2011;14(4): 261-277.

[42] Eriksson L, Garvill J, Nordlund AM. Interrupting habitual car use: The importance of car habit strength and moral motivation for personal car use reduction. Transportation Research Part F: Traffic Psychology and Behaviour. 2008;11(1): 10-23.

[43] Dargay J. The effect of prices and income on car travel in the UK. Transportation Research Part A: Policy and Practice. 2007;41(10): 949-960.

[44] Liu Y, Hong Z, Liu Y. Do driving restriction policies effectively motivate commuters to use public transportation? Energy Policy. 2016;90: 253-261.

[45] Bamberg S, Rölle D, Weber C. Does habitual car use not lead to more resistance to change of travel mode? Transportation. 2003;30(1): 97-108.

[46] Schmidt P, Davidov E, Banberg S. Is there any interaction effect between intention and percevies behavioural control? Methods of Psychological Research Online. 2004;8(2): 127-157.

[47] Bamberg S, Schmidt P. Incentives, morality, or habit? Predicting students' car use for university routes with the models of Ajzen, Schwartz, and Triandis. Environment and Behaviour. 2003;35(2): 264-285.

[48] Ye R, Titheridge H. Satisfaction with the commute: The role of travel mode choice, built environment and attitudes. Transportation Research Part D: Transport and Environment. 2016;52: 535-547.

[49] Jia N, Zhang Y, He Z, Li G. Commuters' acceptance of and behaviour reactions to license plate restriction policy: A case study of Tianjin, China. Transportation Research Part D: Transport and Environment. 2016;52: 428-440.

[50] Zhang LL, Long RY, Chen H. Do car restriction policies effectively promote the development of public transport? World Development. 2019;119: 100-110. 